\title{
Where Are the Women? The Presence of Female Columnists in U.S. Opinion Pages
}

Journalism \& Mass Communication Quarterly 2014, Vol. 91 (2) 289-307

(c) 2014 AEJMC

Reprints and permissions: sagepub.com/journalsPermissions.nav

DOI: $10.1177 / 1077699014527457$ jmcq.sagepub.com

$\Theta$ SAGE

\section{Dustin Harp', Ingrid Bachmann², and Jaime Loke ${ }^{3}$}

\begin{abstract}
Empirical and anecdotal evidence shows that the news media are male-dominated. This study updates the extant literature on women's representation in the op-ed pages of ten U.S. newspapers. A content analysis showed that female authors are moving beyond topics traditionally linked to females and are writing columns on topics such as politics and economy. However, they remain a minority, and, thus, women's voices have yet to gain more visibility in the world of opinion writing in U.S. journalism.
\end{abstract}

\section{Keywords}

print media, content analysis, gender, professional issues

Opinion pages illustrate an area of American journalism notorious for its lack of diversity. Deborah Howell of the Washington Post explained the problem simply when she wrote the opinion page is often "too male and too white." explanations for why women are not featured more on opinion pages, such as gender enculturation, by which women are raised to believe they are not qualified nor have the right to voice their opinions; the male-dominated culture of newsrooms, where women have traditionally been marginalized and offered fewer opportunities; and

\footnotetext{
IUniversity of Texas at Arlington, Arlington, TX, USA

2Pontificia Universidad Católica de Chile, Santiago, Chile

3University of Oklahoma, Norman, OK, USA

\section{Corresponding Author:}

Dustin Harp, Department of Communication, University of Texas at Arlington, Box 19107, 700 West Greek Row, 118 Fine Arts Building, Arlington, TX 76019.

Email: dustinh@uta.edu
} 
women's opting out of these intensive and time-consuming positions because of parenting and family responsibilities. ${ }^{2}$ The reasons then for the lack of women's voices on opinion pages include both women's self-selection out of the job, as well as their inability to get the job. The interplay of these cultural and organizational explanations makes the issue quite complicated.

Catherine Orenstein, founder of the U.S.-based The Op-Ed Project, designed to include more women in public conversations, especially in media outlets, said women often "discount themselves and their knowledge." ${ }^{3}$ Historically, women have been discouraged to speak up because any display of knowledge for women indicated unladylike qualities, such as aggression and conceit. ${ }^{4}$

Nick Coleman, a former columnist for the (Minneapolis, Minnesota) Star Tribune, noted another reason women may be less interested in opinion writing, at least in the United States: a gender gap in hate mail. Coleman said, "My wife is also a columnist at the St. Paul Pioneer, and there is a huge difference between the types of abuse I get, and what she gets. It's much worse for her." ${ }^{5}$ The content of the hate mail his wife, Laura Billings Coleman, received focused on the fact that she is a woman and references were often made to her appearance.

Despite progress, U.S. newsrooms remain very much male domains. Females made up more than $64 \%$ of journalism school graduates in 2010, but statistics released by the American Society of News Editors (ASNE) showed females only represented $36.9 \%$ of full-time, daily newsroom journalists at that time - that is, 15,400 females, whereas males totaled more than $26,300 .{ }^{6}$ In fact, females have been graduating from journalism schools at a higher rate than males since the 1970s, so a lack of capable women cannot be seen as the problem. ${ }^{7}$ While clearly not all of these females graduating from journalism schools seek newspaper jobs, it is likely there are enough women - who are capable and willing - to occupy $50 \%$ of the positions available in U.S. newsrooms. However, the research available tells a story of male-dominated spaces that can be both overtly and subtly unfriendly to females, resulting in women occupying fewer management positions, being paid less than their male counterparts, and leaving the newsroom earlier in their careers. ${ }^{8}$ It follows, then, that for newspapers to feature more female columnists on the editorial pages, the culture of newsrooms must be more inclusive of women overall.

Surprisingly, or perhaps not, there is a dearth of research surrounding female columnists and the columns they write. This study provides evidence of women's presence and voices on opinion pages in U.S. dailies. Examining ten newspapers from across the country - selected based on circulation size and nine regions of the country and including USA Today for its status as a national newspaper-the present study offers a status report on the numbers of women sharing their opinions and includes details about what topics these women are likely to cover, what sources they rely on, and how or if they might use a so-called woman's voice. Such state-of-the-issue research is a crucial first step in understanding women's opinion writing in contemporary American journalism. It is essential because it lays the groundwork for further investigations that go beyond merely stating numbers by including considerations of how female columnists write as well. 


\section{Feminist Theoretical Framework}

Relying on feminist theories as a foundation for understanding women's roles in journalism, feminist media scholars have recognized the troubled history of gender and journalism. Historically women have been discouraged from speaking up in public and participating in public discourse. ${ }^{9}$ Although significant progress has been made, women are still often moved to the margins of the mainstream media and have struggled to be treated as equals in the newsroom. ${ }^{10}$ Even when women appear in news, they often do so in stereotypical roles, such as wives, mothers, or victims, and are often invisible in other areas of the public sphere. ${ }^{11}$ Beyond problems with news media content are concerns with women in newsrooms. Women less often write for the front pages of top newspapers in the United States and are often relegated to covering stories about family, food, fashion, and entertainment, rather than the so-called "hard news" subjects of business, politics, and international news. ${ }^{12}$ Women also hold fewer decision-making positions in the newsroom. Data from ASNE showed that in 2013, women made up only $34.6 \%$ of supervising positions in U.S. dailies. ${ }^{13}$ All of these issues - women's (lack of) presence in content, as writers, and as decision-makersare significant to the (lack of) presence of women's voices on opinion pages. Furthermore, not only could women's opinions be heard through female authors, but also through the voices opinion writers use in quotes and as sources. ${ }^{14}$

Feminist theorizing focuses on the ways power in conjunction with gender organizes both the material and symbolic worlds. ${ }^{15}$ According to feminist media scholars, media provide ideological support for hegemonic power structures. ${ }^{16}$ In an American context, this includes a patriarchal power structure. However, rather than simply identifying the problems with ideology, hegemony, and media, feminism is committed to intervening and transforming these systems of power in terms of both media practices and content. ${ }^{17}$ Fraser noted how dominant groups by gender, race, and class control the ways a society communicates and interprets information. In other words, the hegemonic group drives the use of official vocabularies, rhetorical devices, idioms for communicating one's needs, and the paradigms of argumentation accepted as authoritative. ${ }^{18}$ For these reasons, it is essential that on opinion pages and in commentary writing - where issues about our communities and world are defined and solutions are offered - that a diverse group of voices be represented. This notion of diversifying the newsroom to add female voices in equal numbers to men's voices does not necessarily mean that with more women's voices will come a louder and distinctly gendered women's voice. On the contrary, it ensures diversity by allowing various women's perspectives to be represented. This reflects a contemporary understanding of feminism, unlike the feminism marked by Betty Friedan's seminal book, The Feminine Mystique, that essentially ignored differences between women as she argued for what women wanted. ${ }^{19}$ Contemporary feminist theorizing strives to acknowledge the differences among women. Within the context of opinion pages of American newspaperswhether published in print or online - a contemporary feminist goal would be to have a diverse number of females (and diversity of people in general) writing and appearing on these pages. This does not ensure a distinct feminist voice, but rather a broad array 
of voices. With this call for female voices of varied perspectives, we also acknowledge that males can have a feminist voice, as feminist is a social and political perspective and not a sex or gender trait. ${ }^{20}$

From within a feminist theoretical framework, feminist ethics offers not only a means from which to analyze problems that emerge in media content and the workplace, but recommends ways to resist oppressive practices and subscribe to alternatives that promote emancipation. ${ }^{21}$ As such, Steiner explains, "Feminist ethics is concerned with how people can live together with others in healthy, productive ways and how we can build social or political structures to support this." 22 Feminist ethics is thus particularly relevant to the discussion of women's voices on opinion pages because of the ethical considerations essential to speech, the silencing of speech, who gets to speak, who does not, and who is listened to and not listened to. ${ }^{23}$ Ethical reflection, often a philosophical pursuit, leads to questions about what should be done. From a feminist ethical standpoint, a multitude of women's points of view should be heard and integrated into public discourse. Opinion pages and columnists in American newspapers hold a privileged position in cultural discourse, occupying a sanctioned space from which to analyze, critique, and offer solutions on relevant societal issues. ${ }^{24}$ Thus, from a critical standpoint, it is an ethical obligation to provide diversity in those voices, including gender diversity.

\section{Literature Review}

\section{Gender and the News Industry}

Research consistently shows that women are not treated equally in or by the news media industry. ${ }^{25}$ In the late 1970 s, Tuchman labeled the pervasive exclusion of women and women's issues as legitimate topics of news media "symbolic annihilation." ${ }^{26}$ Such exclusion of women from a mediated view is important because mass media inform people's understanding of women as subjects and actors in society. ${ }^{27}$ News coverage too frequently tells a rather monolithic account of women's concerns (e.g., home, family, domestic violence, and sexual relations), and constrains them to the realm of the private world, while the proper masculine interests "are left to constitute the real substance of public sphere discourse." ${ }^{28}$ This framing of issues perpetuates a narrow and dichotomous understanding of our world. Feminist scholars stress that mainstream news media are strongly linked to the political and economic interests of men, to the extent that news media are largely produced for a male - and whiteaudience and based upon masculine definitions of newsworthiness. ${ }^{29}$

Empirical evidence shows that the penchant toward erasing women and their interests is widespread and remains an issue in the news industry today, particularly daily newspapers. ${ }^{30}$ Indeed, women are less likely than men to be sources or appear in authoritative roles ${ }^{31}$ are consistently depicted less frequently than males, ${ }^{32}$ and have a lesser prominence, such as appearing further down in stories, with fewer quotes or only paraphrased, and in relation to topics deemed less substantive, such as parenting, education, or gardening. ${ }^{33}$ 
When examining women working in the industry, the story reveals a similar tale. The world of journalism is male-dominated, with men comprising the majority in newsrooms and editorial positions. According to ASNE, in 2013, women accounted for $36.3 \%$ of all newspaper jobs and $34.6 \%$ of supervising positions - percentages that have remained stable for two decades. While women have made up the majority of journalism graduates in the United States since 1977, currently females write only one in seven news articles. ${ }^{34}$ In a recent study measuring the number of female bylines in the New York Times for the first two months in 2013, the results showed that men had twice the number of bylines as females. ${ }^{35}$ Along those lines, Everbach and Flournoy found that women in the journalistic field complain about the lack of opportunity, low salaries, and differing perspectives on news, which leads them to leave full-time positions. ${ }^{36}$ The scenario is even gloomier in traditionally male-dominated beats, such as sports. ${ }^{37}$ It is clear, then, that there are barriers in the industry that limit women's participation and advancement in the news industry.

The underrepresentation of women in the media is not a minor issue. It shows the inability of media to reflect different life experiences and perspectives, and thus presents an inaccurate picture of the world. As San Jose Mercury News former executive editor David Yarnold argued, "If readers don't see themselves and hear their voices in your pages, they won't view you as a credible source of information." ${ }^{38}$ ASNE itself has acknowledged that diversity - including gender, age, race/ethnicity, and sexual orientation - is not only important, but also necessary. Furthermore, the importance of preserving viewpoint diversity is an argument used by advocates of legal regulation of media ownership to limit ownership consolidation..$^{39}$

\section{Diversity in the Op-Ed Pages}

Another place where newspaper editors could embrace more gender diversity is on their editorial boards and opinion pages. The historically scarce presence of women in editorial positions conveys the message that women are not worth listening to and that a woman's point of view is not valued in an editorial setting. ${ }^{40}$ Indeed, if the news industry is male-dominated, the op-ed pages are essentially a male kingdom. Studies published in 2005 by Editor \& Publisher found that the percentage of female columnists in syndication was "low" and that the number of female editorial cartoonists was "pathetic"-accounting for only about $4 \%$ of the total. ${ }^{41}$

Writing a column is deemed an important and coveted assignment in print (including online) journalism, ${ }^{42}$ but considering the constraints for women in the newspaper industry and gender bias in newsrooms and culturally, ${ }^{43}$ it is not a surprise that it is an endeavor dominated by men. Interestingly, the first American to work as a newspaper columnist as the job is understood today- "someone paid a salary to write a regular, signed opinion piece" - was a female, Sara Willis Parton, who wrote under the penname of Fanny Fern. ${ }^{44}$ At $\$ 100$ per column when she began writing for the New York Ledger in 1856, she was the highest paid newspaper writer at the time. ${ }^{45}$

But Fanny Fern was an exception, not the rule, and throughout the twentieth century the majority of female columnists - few as they were-appeared mostly in the 
women's pages of U.S. newspapers. ${ }^{46}$ Such segregated underrepresentation creates a pervasive impression that women's voices and opinions are unimportant compared to male counterparts, and that females have little that is meaningful to say outside of the stereotypical domestic domain of family, food, fashion, and furnishings. ${ }^{47}$ The message seems to have reached females themselves, as anecdotal and empirical evidence suggest that many women do not think they have the merits or credentials to contribute to opinion pages. ${ }^{48}$ As Andsager and Mastin argued, "the fact that white males dominate the op-ed pages of many [American] newspapers might lead one to believe that readers perceive white males to be the most expert and trustworthy sources for opinion on political, economic, and social issues." 49 However, in their experiment, these authors found female columnists were ascribed greater credibility than males in general, but the difference was not statistically significant, suggesting that the underrepresentation of women and minorities has more to do with media institutions' male perspectives and hiring practices than with audience biases.

Some evidence also suggests the inclusion of more females is not only a matter of gender equality, but also a better reflection of society as a whole because the typical American woman communicates differently than the typical man, resulting in a distinct female voice. Tannen, for instance, argues that women's way of making sense of the world tends to integrate personal experience to a greater extent than men. ${ }^{50}$ Research also shows female and male journalists display subtle professional differences when it comes to journalism and reporting - for instance, how they frame issues or the preference for a negative or positive tone ${ }^{51}$-and some women in the news industry argue that their perspective is different..$^{52}$ According to Everbach's study of newsroom culture, the same goes for editorial boards and other leadership positions, where individuals make important decisions regarding news content and newsroom culture. ${ }^{53}$ While we do not subscribe to the notion of an essential female or male voice and also recognize the controversial nature of such research, these cited studies suggesting differences in male and female practices of communication and journalism offer a further argument for the importance of diversifying opinion pages.

In the context of previous research, an exploration of female columnists in the United States's most prominent newspapers is a timely endeavor offering an updated account of inroads and a marker for setting pending goals in women's representations in the news media. Mass communication scholarship "has largely ignored the op-ed page, ${ }^{, 54}$ and thus we hope to fill a void in current journalism and feminist literature.

\section{Research Questions and Hypothesis}

Based on past literature and the ongoing debate on female representation among op-ed pages, we posit the following research questions and hypothesis:

RQ1: How gender-balanced are the editorial boards of major U.S. newspapers?

RQ2: Currently, what kind of topics do female columnists write about?

RQ3: How often do female columnists include personal details in their columns?

H1: Most female columnists will be experienced journalists who have spent a significant amount of time in the field of journalism. 


\section{Method}

To answer our research questions and test our hypothesis, we conducted a content analysis of columns published by major newspapers across the United States. This approach allowed for a quantitative assessment of newspaper columns penned by women.

Based on the U.S. Circulation Bureau's nine regional divisions, we selected the newspaper with the largest circulation in each division: the Boston Globe (New England), the New York Times (Mid-Atlantic), ${ }^{55}$ the Chicago Tribune (East North Central), the Minneapolis Star Tribune (West North Central), the Washington Post (South Atlantic), the Louisville (KY) Courier-Journal (East South Central), the Dallas Morning News (West South Central), the Arizona Republic (Mountain), and the Los Angeles Times (Pacific). To complete our sample, we included USA Today as a national newspaper. Arguably, these newspapers, the most prominent in their respective regions, have the financial and journalistic means to have a more gender-balanced pool of commentary writers and editorial board members. They might also set the standard for the industry in regards to diversity and the inclusion of female voices.

We collected all columns written by a female columnist, or at least one female author in the case of multiple authors, in these newspapers during October 2011 and April 2012. The purposive sample responded to an effort to tap into different time periods while avoiding ones with slower news cycles, like summer and the end-of-year holidays.

This resulted in 312 columns (for a breakdown, see Table 1), excluding duplications and pieces published in more than one newspaper due to syndication. ${ }^{56}$ In addition to identification variables, we coded for the column's primary and secondary topic (including politics, lifestyle, education, health, economics, arts, parenting, armed forces, legal affairs, and fashion), ${ }^{57}$ whether the author was syndicated, whether newspaper staff or a guest writer penned the column, and the years of experience in the news industry of each author. In addition, we coded for the basis of the arguments used in the columns (i.e., citation/sources, personal accounts and anecdotes, statistics and numbers, and other), and counted the number of both males and females cited (quoted or paraphrased), as well as males and females mentioned (but not cited) in the columns. The codebook also asked whether the discussion addressed women's issues from a feminist standpoint, and whether the column included the words "feminist(s)" or "feminism." Inter-coder reliability was calculated using Scott's $p i$ in a subsample of $10 \%$ of the columns. The scores were .87 for primary topic and .85 for secondary topic. All the other variables had a pi value of 1.0.

We used the quantitative data from the content analysis as generalizable evidence, but also relied on a qualitative assessment of the arguments, tone, and issues discussed in the columns. Descriptive statistics and cross-tabulations helped to analyze the results. Because this is a census of columns written by women, inferential statistics were not necessary for the analysis.

In addition, we collected information on the gender and racial makeup of each newspaper's editorial board, as research suggests that more gender-balanced newsrooms and boards may influence newspaper content. ${ }^{58}$ Our goal was to get an updated picture of women's leadership positions and prominent opinion-sharing posts. 
Table I. Sample Overview.

\begin{tabular}{|c|c|c|c|c|}
\hline Division & States & Newspaper & Circulation & Columns \\
\hline New England & $\begin{array}{l}\text { Maine, New Hampshire, Vermont, } \\
\text { Massachusetts, Rhode Island, } \\
\text { Connecticut }\end{array}$ & Boston Globe & 303,000 & 47 \\
\hline Mid-Atlantic & New York, Pennsylvania, New Jersey & New York Times & $1,040,000$ & 37 \\
\hline $\begin{array}{l}\text { East North } \\
\text { Central }\end{array}$ & $\begin{array}{l}\text { Wisconsin, Michigan, Illinois, Indiana, } \\
\text { Ohio }\end{array}$ & Chicago Tribune & 501,000 & 59 \\
\hline $\begin{array}{l}\text { West North } \\
\text { Central }\end{array}$ & $\begin{array}{l}\text { Missouri, North Dakota, South } \\
\text { Dakota, Nebraska, Kansas, } \\
\text { Minnesota, lowa }\end{array}$ & $\begin{array}{l}\text { Minneapolis Star } \\
\text { Tribune }\end{array}$ & 378,316 & 34 \\
\hline $\begin{array}{l}\text { South } \\
\text { Atlantic }\end{array}$ & $\begin{array}{l}\text { Delaware, Maryland, District of } \\
\text { Columbia, Virginia, West Virginia, } \\
\text { North Carolina, South Carolina, } \\
\text { Georgia, Florida }\end{array}$ & Washington Post & 735,617 & 32 \\
\hline $\begin{array}{l}\text { East South } \\
\text { Central }\end{array}$ & $\begin{array}{l}\text { Kentucky, Tennessee, Mississippi, } \\
\text { Alabama }\end{array}$ & $\begin{array}{l}\text { Louisville } \\
\text { Courier-Journal }\end{array}$ & 215,734 & 27 \\
\hline $\begin{array}{l}\text { West South } \\
\text { Central }\end{array}$ & Oklahoma, Texas, Arkansas, Louisiana & $\begin{array}{l}\text { Dallas Morning } \\
\text { News }\end{array}$ & 425,000 & 19 \\
\hline Mountain & $\begin{array}{l}\text { Idaho, Montana, Wyoming, Nevada, } \\
\text { Utah, Colorado, Arizona, New } \\
\text { Mexico }\end{array}$ & Arizona Republic & 390,000 & 44 \\
\hline Pacific & $\begin{array}{l}\text { Alaska, Washington, Oregon, } \\
\text { California, Hawaii }\end{array}$ & $\begin{array}{l}\text { Los Angeles } \\
\text { Times }\end{array}$ & 894,943 & 19 \\
\hline National & NA & USA Today & $2,1 \mid 4,000$ & 14 \\
\hline
\end{tabular}

\section{Results}

In answering RQ1, our analysis shows that the editorial boards of the newspapers are overwhelmingly male. On average, there are eleven members on each board, but only four women. Whites also dominate the board, averaging eight of eleven members. When looking at the list of editorial columnists, the picture is just as grim: on average, there are twenty-two columnists - six of them females, and only one of these an ethnic or racial minority. As Figure 1 illustrates, the editorial boards and editorial columnists of these ten prominent national American newspapers are overwhelmingly male and white. Furthermore, the Boston Globe stood as the newspaper with the lowest proportion of women on their editorial board ( $20 \%$, or two members out of ten), whereas the Minneapolis Star Tribune had the highest proportion (57\%, or four out of seven members).

In addition, our analysis yielded ninety-nine different female authors, thirty-eight of them syndicated. Only seven of the columns (2.2\%) listed a co-author, usually a man. Laurie Roberts, from the Arizona Republic topped the list as the most prolific columnist, followed by syndicated authors Kathleen Parker and Juliet Kayyem. Overall, syndicated columns were more likely to be published on a Tuesday, whereas staff-penned columns tended to appear more often on Fridays. Guest writers-invited 


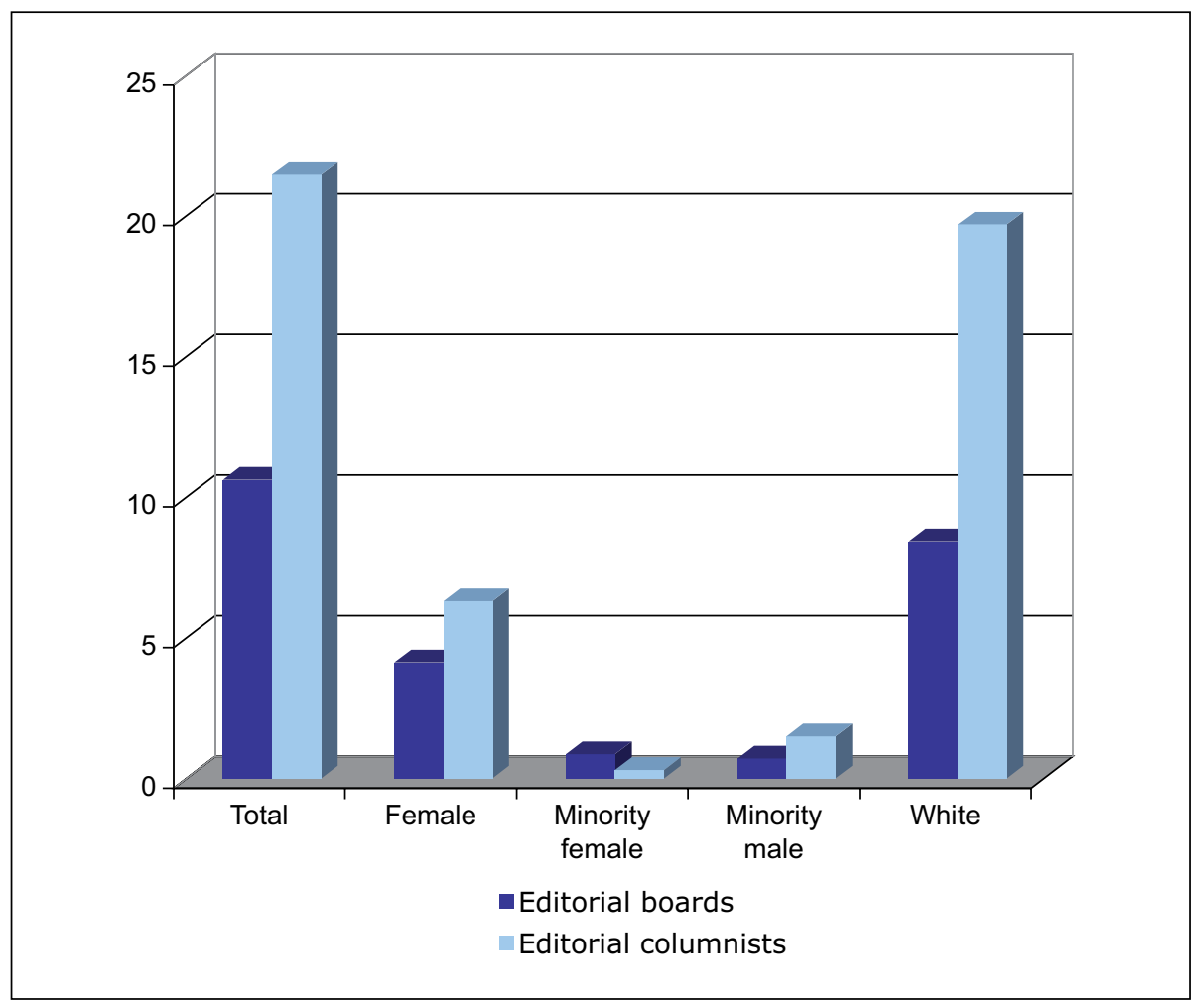

Figure I. Gender and race distribution of editorial board members and editorial columnists.

columnists - were more likely to write about miscellaneous topics, such as lifestyle, as well as education and health.

RQ2 asked what topics female columnists write about. The columns proved to cover a wide array of topics. Surprisingly, as women have traditionally more often covered issues related to family and home, politics - a traditionally masculine topicwas the most popular topic covered in these columns $(34.0 \%)$, particularly at the Washington Post and among syndicated columnists (see Table 2). This signals an important inroad for female columnists, as women are usually marginalized in debates regarding public affairs and policy issues. ${ }^{59}$ Of course, the fact that opinion pages traditionally cover political issues might help to explain this finding. Other popular topics included business and economics (8.0\%) - another masculine domain - health (5.8\%), education (5.4\%), and sports (4.2\%). ${ }^{60}$ A total of eighteen stories (almost $6 \%$ of the sample) discussed gender issues, often times with regards to the so-called "war on women" in several legislatures or gender gaps discussed in the context of the 2012 election campaign. Thus, in answering RQ2, female columnists have broadened somewhat beyond stereotypically feminine topics, with two-fifths of the columns covering politics and economic issues. 
Table 2. Female Columnist Profile by Newspaper.

\begin{tabular}{|c|c|c|c|c|c|}
\hline Newspaper & Columns & $\begin{array}{c}\text { Number of } \\
\text { authors }\end{array}$ & $\begin{array}{l}\text { Number of } \\
\text { staff writers }\end{array}$ & $\begin{array}{l}\text { Number of } \\
\text { guest writers }\end{array}$ & $\begin{array}{l}\text { Most common } \\
\text { topic }\end{array}$ \\
\hline Arizona Republic & 44 & 6 & 5 & 0 & Politics (36.4\%) \\
\hline Boston Globe & 47 & 6 & 3 & 3 & Politics (40.4\%) \\
\hline Chicago Tribune & 59 & 11 & 8 & 3 & $\begin{array}{l}\text { Business and } \\
\text { economy (23.8\%) }\end{array}$ \\
\hline Dallas Morning News & 19 & 14 & 4 & 10 & Politics (36.8\%) \\
\hline Los Angeles Times & 19 & 10 & 4 & 6 & Politics (42.1\%) \\
\hline Louisville Courier-Journal & 27 & 17 & 5 & 12 & Politics (22.9\%) \\
\hline Minneapolis Star Tribune & 34 & 14 & 3 & 11 & Politics (32.4\%) \\
\hline New York Times & 37 & 16 & 4 & 12 & Politics (32.4\%) \\
\hline Washington Post & 32 & 9 & 4 & 5 & Politics (75.0\%) \\
\hline USA Today & 14 & 13 & 4 & 9 & Health (28.6\%) \\
\hline
\end{tabular}

A breakdown by newspaper shows the diversity of female columnists, in numbers as well as their status (see Table 2). The Chicago Tribune had the highest number of women-penned columns $(n=59)$, most of them by staff writers or regular contributors. Conversely, USA Today had only fourteen columns penned by women, by thirteen different authors, eight of them syndicated. As for topics, the Boston Globe (1) and USA Today (1) were the only newspapers with columns that included the armed forces topic, and the Arizona Republic had the highest proportion of columns dealing with both parenting $(11.4 \%, n=5)$ and legal affairs $(6.8 \%, n=3)$. In the Dallas Morning News education proved particularly prominent $(21.4 \%, n=4)$, while the Los Angeles Times had the only column on fashion.

In addressing RQ3 inquiring how frequently female columnists included personal details in their columns or wrote from a distinctly women's voice, this study revealed that the personal was not popular. Arguably, this has to do with journalistic norms dictating that journalists keep themselves out of their work, ${ }^{61}$ and while this is largely understood within the context of news objectivity, the normative value may bleed into opinion writing as well. The most common basis for commentary provided were citation or sources $-76.6 \%$ of the columns relied on this kind of evidence to make their case. An example of a column coded as such was one penned by Juliette Kayyem regarding Saudi Arabia's stance on female Olympians. In the article, citing Prince bin Faisal, Kayyem wrote, "But Saudi Arabia just confirmed that they will not be "endorsing any female Saudi participation.' Sports head Prince bin Faisal noted 'there are hundreds, if not thousands, of women who practice sports, but in private."'62

A quarter $(25.6 \%)$ of columns relied on personal anecdotes or accounts, most prominently in the Dallas Morning News and the Arizona Republic, and particularly in invited (non-staff) columns. For example, in a column by LaDawn Fletcher on childhood sexual assault, she wrote, "And in my own personal experience, I have found that to be true. As I began to share what I was learning, people in my rainbow coalition of friends started sharing their own personal experiences." ${ }^{63}$ In another example of a 
columnist using a personal account, found in a column by Ada Brown of the Dallas Morning News, the author wrote,

When I was growing up, every time my family drove by the public pool in a neighboring town, my dad said that someday he was going to stop and swim. When he was a kid, the pool was for whites only. Now that he can swim there if he wants to, he says he's no longer interested. ${ }^{64}$

Other columns relied on statistical information (28.5\%), knowledge claims, analyses or something similar (24.4\%), or a combination of these sources. For example, in an opinion piece by Joanna Weiss at the Boston Globe, coded as relying on statistical information, she stated, "According to Census data, in 2010, only 23 percent of families with married parents and children under 15 had stay-at-home moms." 65

On average, the authors cited 1.1 male and 0.6 females per column; they also mentioned 1.1 males and 0.5 females. Almost $15 \%$ of the stories cited 3 or more men, but fewer than $5 \%$ cited 3 or more women. A breakdown by newspaper shows that the Louisville Courier-Journal cited on average almost 2 men per column, whereas the columns in the Washington Post, with a mean of 0.2, were the least likely to cite women. Regarding names mentioned, none of the newspapers averaged more than 1 female mentioned or discussed in the columns, while columns in newspapers like the New York Times or the Washington Post averaged 2.7 and 2.4 males mentioned per column. The gap increased in columns addressing topics such as politics, business and economy, and sports.

Likewise, only thirty-two (10.3\%) columns discussed topics from a feminist standpoint, and only nine stories included the word "feminist(s)" or "feminism"- and not necessarily within a positive or meaningful frame. In an example that does demonstrate a positive portrayal of feminism, Joan Wickersham wrote a column discussing her favorite children's book. A paragraph in the column stated,

Yet 70 years ago, in its gentle, pastel way, 'The Country Bunny' was presciently, bracingly feminist, with its story of a female in a male world who, against all odds, is chosen for a job by a discerning employer who sees and values her intelligence, strength, and wisdom. ${ }^{66}$

Another example that contained the term "feminist," but not discussed as either positive or negative, was Joan Vennochi's article regarding the pope's treatment of nuns. In a paragraph, she wrote, "An American bishop is now charged with reeling them in, after the investigation revealed 'serious doctrinal problems' relating to 'radical feminist themes incompatible with the Catholic faith." 67 The article detailed primarily convictions of several priests' sexual abuse cases and did not mention feminism after that initial term.

H1 hypothesized most female columnists will be experienced journalists who have spent a significant amount of time in the field of journalism. The hypothesis was supported. Most of the female columnists have had long careers in journalism. On average, these columnists had been in the field for twenty-four years and more than a third 
(35.6\%) of the staff op-ed writers had been in the business for at least thirty years. Admittedly, commentary writing is hardly an entry-level position, and these prominent newspapers are likely to hire well-known, established writers. However, in the context of research that has found some women tend to leave full-time journalism jobs at early stages in their careers, ${ }^{68}$ this reality is both explanatory and concerning. The fact that only four columnists had less than ten years of experience also reinforces this point. Together the data indicate that within the current realities of the journalism culture, women - by leaving the profession early — might be effectively cutting off their already slim chances to become column writers.

\section{Discussion and Conclusion}

This research is a status report, offering data on women's roles as columnists and opinion writers in U.S. dailies. The results offer reasons for cautious celebration, as well as frustration. This study revealed that although inroads have been made to include more females in the public sphere of commentary and opinion, there remains much work to be done before female voices achieve the same level of participation as male writers. Such research is important and has broad implications because, as Braden argued two decades ago ${ }^{69}$ putting a column by a woman on the same page as columns written by men has symbolic value and sends a message that women's opinions matter and women are worth taking seriously. Moreover, scholars have argued that gender equality cannot be achieved in the United States if females do not have access to and equal representation in cultural symbols of power such as the op-ed pages. $^{70}$ If on a daily basis female voices are silenced within the dialogue fostered by (print and online) newspapers - a marker of the public sphere- how can women be viewed as valid interlocutors in public debate?

Our study shows that while there have been some important inroads and there are signs of greater gender equality, opinion writing remains a male kingdom. A look at the editorial boards of the newspapers analyzed shows that most members are white men. Thus, the editorial voice of a newspaper - its opinions, its endorsements, its critiques - has much more to do with the perspectives, interests, and concerns of men, particularly white men. While in no way do we suggest that all white males think alike or that all females think alike, we argue that diversity of all kinds on the editorial board and pages of newspapers is essential to ensure diverse perspectives in the public sphere. In other words, while race and gender differences do not translate automatically into differences in thought, experiences - whether they are based on gender, race and ethnicity, or sexual orientation-can influence one's perspective. A multitude of experiences represented by a diverse group of voices will better reflect a culturally diverse community and help to achieve goals set out by contemporary feminist ethics and philosophy.

Furthermore, within the framework of democratic theory and the role of journalism within that perspective, it is a matter of fairness that representation be more equal. With females making up more than $50 \%$ of the population in the United States, the 
diverse perspectives females bring to public dialogue should be more frequently represented on the pages of American newspapers.

The fact that in eight out of the ten newspapers analyzed politics was the most common topic addressed by female columnists suggests that women are gaining ground in areas traditionally and discursively reserved for men. Our research clearly indicates that female columnists - when they are permitted to join the conversation — are participating in opinion exchanges related to public affairs, policy, and politics, and are not limited to domestic and private concerns, such as food or parenting. That said, most of the columns about politics were written by guest columnists and not staff writers, and the overall analysis shows that on average, women constitute fewer than a quarter of the op-ed writers of these newspapers. Also discouraging, most of the female staff columnists had more than twenty years of career experience, a fact that might be an indication of how the glass ceiling still exists in the news industry and its op-ed pages. Why more female staff are not writing for opinion pages and how their experiences compare to their male counterparts in the newsroom need further research.

As Steinem noted, feminist ethics is concerned with promoting means for changing oppressive practices. ${ }^{71}$ Rockwell stated, "a goal of feminism is to produce work that emerges organically to change the material lives of those influenced by it." 72 Monitoring women's representation in editorial boards and op-ed pages - and thus, creating awareness - is just one step in promoting change. Organized campaigns - in the form of letters to editors - demanding that editorial pages offer a balanced and diverse group of voices might be a productive next step. Organizations like the $O p-E d$ Project that strives to increase the range of voices heard in the public sphere and has had more than 3,000 female experts participate in its program are an excellent starting point. This effort alone has resulted in hundreds of opinion pieces by females published in major media outlets.

Feminist ethics is crucial to this discussion because theoretically the voices that are able to participate most actively in the public sphere are the ones who are heard most often and have the most impact. These voices on the opinion pages then are theoretically able through mainstream media to ignite change. Female voices in this arena are important, but may become especially so when, for example, particular issues related to females become part of public discourse. One such case is the recent rancorous debate regarding women's health and reproductive rights playing out in the U.S. political arena.

The results of this study are important for providing groundwork for future research and are part of a larger project that includes qualitative textual analysis of female columnists' work. While the sample is not representative (results are at most generalizable to the ten newspapers analyzed), the findings did show a pattern of exclusion that should be further investigated. A content analysis like ours can only offer a descriptive account of newspaper content and cannot illuminate the audience's response to the scarce numbers of female columnists and their lack of voice in the press. Thus, more studies and other methods are needed to more fully understand the issue and consequences of the results found. Examinations of online publications would be especially 
beneficial considering the state of the newspaper industry and the move to online content.

The authors of this study also acknowledge that gender is only one element of diversity. There are also issues of class, race/ethnicity, and sexual orientation that should be addressed as well. Nonetheless, gender offers a means to begin to understand power relationships and hegemony within the op-ed pages. In addition, we firmly believe a feminist theoretical framework indicates interest in and conclusions beyond that of only women. The influence of feminist research

expands well beyond the bounds of male/female power relationships. This expansion addresses marginalization or political oppression of all humanity with regard to the materiality of language and bodies. In that sense, research on communication and gender focuses a critical eye on the powerful, and grants genuine empathy toward Others who suffer. ${ }^{73}$

That said, this study updates and expands previous research, addresses the largely ignored area of opinion writing in U.S. newspapers, and provides an update on where female columnists in ten major news publications stand today. It is important to constantly measure the progress of female columnists, as there needs to be vigilance in keeping track of whether female columnists are breaking barriers or if they are regressing toward a weaker presence on the opinion pages. Having a strong presence on the opinion pages does not end at merely having the privilege to write columns. It is a nod of acceptance that the columnist's opinions matter and that they are worthy of having a personal opinion in a major publication. It is a seal of approval that this columnist deserves space to express her ideas. And so with these implicit connotations that accompany the role of a columnist, it is imperative that more females have a stronger presence on these pages to send the message that, yes, women's voices are worthy to participate in the public sphere.

\section{Declaration of Conflicting Interests}

The author(s) declared no potential conflicts of interest with respect to the research, authorship, and/or publication of this article.

\section{Funding}

The author(s) received no financial support for the research, authorship, and/or publication of this article.

\section{Notes}

1. Deborah Howell, “An Op-Ed Need for Diverse Voices,” Washington Post, May 25, 2008, http://www.washingtonpost.com/wp-dyn/content/article/2008/05/23/AR2008052302308. html (accessed October 10, 2012).

2. Maurine H. Beasley and Sheila J. Gibbons, Taking Their Place: A Documentary History of Women and Journalism, 2nd ed. (Washington, DC: American University Press, 2003); Cindy Elmore, “Two Steps Forward and One Step Back: Coverage of Women Journalists 
in Editor \& Publisher 1978 through 1988," American Journalism 20 (fall 2003): 33-54; Cindy Elmore, "Recollections in Hindsight from Women Who Left: The Gendered Newsroom Culture," Women \& Language 30 (spring 2007): 18-27; Tracy Everbach and Craig Flournoy, "Women Leave Journalism for Better Pay, Work Conditions," Newspaper Research Journal 28 (summer 2007): 52-64; Karen Ross and Cynthia Carter, "Women and News: A Long and Winding Road," Media, Culture \& Society 33 (November 2011): 1148-65.

3. Mallary J. Tenore, "Why Women Don't Contribute to Opinion Pages as Often as Men \& What We Can Do about it," Poynter, February 25, 2011, http://www.poynter.org/latestnews/top-stories/118696/why-women-dont-contribute-to-opinion-pages-as-often-as-menwhat-we-can-do-about-it/ (accessed April 24, 2011), paragraph 4.

4. For instance, Carolyn Byerly and Karen Ross, Women and Media: A Critical Introduction (Malden, MA: Blackwell Publishing, 2006); Nancy Fraser, "Rethinking the Public Sphere," in The Cultural Studies Reader, ed. Simon During (London: Routledge, 1993), 518-36; Karen Ross, Women, Politics, Media: Uneasy Relations in Comparative Perspective (Cresskill, NJ: Hampton Press, 2002); Lisbeth van Zoonen, Feminist Media Studies (London: SAGE, 1994).

5. Heidi Schnakenberg, "Female Pundits Could Use Help with Hate Mail," WeNews, May 24, 2006, http://womensenews.org/story/commentary/060524/female-pundits-could-use-helphate-mail (accessed August 3, 2012).

6. American Society of News Editors, "Newsroom Employment Up Slightly, Minority Numbers Plunge for Third Year," $A S N E$, April 7, 2011, http://asne.org/content. asp?pl=121\&sl=15\&contentid=148 (accessed April 1, 2012).

7. Jennifer Vanasco, "More Women Are Needed in Investigative Journalism," Columbia Journalism Review, March 15, 2013, http://www.cjr.org/minority_reports/need_more lady_investigative_j.php (accessed June 10, 2013).

8. See, for instance, Elmore, "Recollections in Hindsight"; Everbach and Flournoy, "Women Leave Journalism."

9. Byerly and Ross, Women and Media; Fraser, "Rethinking the Public Sphere"; Lana F. Rakow and Kimberlie Kranich, "Women as Signs in Television News," Journal of Communication 41 (March 1991): 8-23; Mary D. Vavrus, Postfeminist News: Political Women in Media Culture (Albany: State University of New York Press, 2002).

10. Beasley and Gibbons, Taking Their Place; Dustin Harp, Desperately Seeking Women Readers: Newspapers and the Construction of a Female Readership (Lanham, MD: Lexington Books, 2007).

11. Dustin Harp, Jaime Loke, and Ingrid Bachmann, "More of the Same Old Story? Women, War and News in Time Magazine," Women's Studies in Communication 34 (November 2011): 202-17; Rakow and Kranich, "Women as Signs in Television News."

12. Maria Braden, She Said What? Interviews with Women Newspaper Columnists (Lexington: University Press of Kentucky, 1993); Carolyn Kitch, "Women in Journalism," in American Journalism: History, Principles, Practices, ed. W. David Sloan and Lisa M. Parcell (Jefferson, NC: McFarland, 2002), 87-96; Vavrus, Postfeminist News.

13. American Society of News Editors, "Total Employment Declines in 2012, but Proportion of Minorities in Newsrooms Remains Stable," ASNE, June 25, 2013, http://asne.org/content.asp?pl=140\&sl=144\&contentid=144 (accessed September 9, 2013).

14. Braden, She Said What?; Harp, Loke, and Bachmann, "More of the Same Old Story?"; see also Rakow and Kranich, "Women as Signs in Television News." 
15. Van Zoonen, Feminist Media Studies.

16. Marian Meyers, New Coverage of Violence against Women: Engendering Blame (Thousand Oaks, CA: SAGE, 1997); Mary D. Vavrus, "Opting Out Moms in the News: Selling New Traditionalism in the New Millennium," Feminist Media Studies 7 (February 2007): 47-63.

17. Linda Steiner, "Feminist Media Studies," in The Handbook of Mass Media Ethics, ed. Lee Wilkins and Clifford G. Christians (NY: Routledge, 2009), 366-81.

18. Nancy Fraser, "Toward a Discourse Ethic of Solidarity," Praxis International 5 (January 1986): 425-29.

19. Betty Friedan, The Feminine Mystique (NY: W. W. Norton, 1963).

20. Harp, "News, Feminist Theories, and the Gender Divide"; Steiner, "Feminist Media Studies."

21. Steiner, "Feminist Media Studies."

22. Linda Steiner, "Feminist Communication Ethics," in The International Encyclopedia of Communication, ed. Wolfgang Donsbach (Oxford, UK: Wiley-Blackwell, 2008), 1769-74.

23. Betty McLellan, Unspeakable: A Feminist Ethic of Speech (Townsville, Australia: Otherwise Publications, 2012); see also Harp, Loke, and Bachmann, "More of the Same Old Story?"

24. See, for instance, Braden, She Said What?; Beasley and Gibbons, Taking Their Place.

25. Dustin Harp, "News, Feminist Theories, and the Gender Divide," in Women, Men, and News: Divided and Disconnected in the News Media Landscape, ed. Paula Poindexter, Sharon Meraz, and Amy Schmitz-Weiss (Mahwah, NJ: Lawrence Erlbaum, 2008), 267-79; Yong Z. Volz and Francis F. L. Lee, "What Does It Take for Women Journalists to Gain Professional Recognition? Gender Disparities among Pulitzer Prize Winners, 1917-2010," Journalism \& Mass Communication Quarterly 90 (summer 2013): 248-66.

26. Gaye Tuchman, "The Symbolic Annihilation of Women by the Mass Media," in Hearth and Home: Images of Women in the Mass Media, ed. Gaye Tuchman, Arlene K. Daniels, and James Benit (NY: Oxford University Press, 1978), 3-38.

27. Byerly and Ross, Women and Media; Ross and Carter, "Women and News."

28. Ross, Women, Politics, Media, 11.

29. Tracy Everbach, "The 'Masculine' Content of a Female-Managed Newspaper," Media Report to Women 33 (fall 2005): 14-22; Rakow and Kranich, "Women as Signs in Television News"; Ross and Carter, "Women and News"; Steiner, "Feminist Communication Ethics"; van Zoonen, Feminist Media Studies.

30. See, for instance, Cory Armstrong, "The Influence of Reporter Gender on Source Selection in Newspaper Stories," Journalism \& Mass Communication Quarterly 81 (spring 2004): 139-54; Eric Freedman, Frederick Fico, and Megan Durisin, "Gender Diversity Absent in Expert Sources for Elections," Newspaper Research Journal 31 (spring 2010): 20-33.

31. Armstrong, "The Influence of Reporter Gender"; Harp, Loke, and Bachmann, "More of the Same Old Story?"; Lynn M. Zoch and Judy V. Turk, "Women Making News: Gender as a Variable in Source Selection and Use," Journalism \& Mass Communication Quarterly 75 (winter 2005): 762-75.

32. Jocelyn Cullity and Prakash Younger, "Gender Imbalance in International Internet News: A Case Study of the BBC," Media, Culture \& Society 31 (November 2009): 999-1009; Maria Len-Rios, Shelly Rodgers, Esther Thorson, and Doyle Yoon, "Representation of Women in News and Photos: Comparing Content to Perceptions," Journal of Communication 55 (winter 2005): 152-78.

33. Cory Armstrong and Fangfang Gao, "Gender, Twitter and News Content: An Examination across Platforms and Coverage Areas,” Journalism Studies 12 (fall 2011): 490-505; Ross, 
Women, Politics, Media; Karen Ross, "The Journalist, the Housewife, the Citizen and the Press: Women and Men as Sources in Local News Narratives," Journalism 8 (August 2007): 449-73; Ross and Carter, "Women and News."

34. Jessica Bennett and Jesse Ellison, "Our Daughters, Ourselves: On 'Women's Equality Day,' A Reality Check," Newsweek, August 26, 2010, http://www.newsweek.com/blogs/ the-gaggle/2010/08/26/our-daughters-ourselves-on-women-s-equality-day-a-realitycheck.html (accessed September 10, 2011).

35. Alexi Layton and Alicia Shepard, "Lack of Female Sources in NY Times Front-Page Stories Highlights Need for Change," Poynter, July 16, 2013, http://www.poynter.org/ latest-news/top-stories/217828/lack-of-female-sources-in-new-york-times-stories-spotlights-need-for-change/ (accessed July 16, 2013).

36. Everbach and Flournoy, "Women Leave Journalism."

37. Marie Hardin and Stacie Shain, "Female Sports Journalists: Are We There Yet? 'No,"' Newspaper Research Journal 26 (fall 2005): 22-35.

38. David Yarnold, "Why Diversity," The Quill 90 (September 2002): 55.

39. Daniel Ho and Kevin Quinn, "Viewpoint Diversity and Media Consolidation: An Empirical Study," Stanford Law Review 61 (February 2009): 781-868.

40. Julie Andsager and Teresa Mastin, "Racial and Regional Differences in Readers' Evaluations of the Credibility of Political Columnists by Race and Sex," Journalism \& Mass Communication Quarterly 86 (spring 2003): 57-72; Beasley and Gibbons, Taking Their Place; Hardin and Shain, "Female Sports Journalists."

41. Dave Astor, "E\&P Study: Percentage of Female Syndicated Pundits Barely Up since 1999," Editor \& Publisher, March 15, 2005, http://www.editorandpublisher.com/Archive/E-ampP-Study-Percentage-of-Female-Syndicated-Pundits-Barely-Up-Since-1999 (accessed March 7 2014); Dave Astor, "Female Op-Ed Columnists Discuss Why There Aren't More of Them," Editor \& Publisher, March 21, 2005, http://editorandpublisher.com/Archive/ Female-Op-Ed-Columnists-Discuss-Why-There-Aren-t-More-of-Them (accessed March 7, 2014).

42. Braden, She Said What?

43. Elmore, "Recollections in Hindsight"; Everbach and Flournoy, "Women Leave Journalism."

44. Kitch, "Women in Journalism."

45. Braden, She Said What?

46. Braden, She Said What?

47. Zoch and Turk, "Women Making News."

48. Braden, She Said What?; Tenore, "Why Women Don't Contribute to Opinion Pages."

49. Andsager and Mastin, "Racial and Regional Differences," 67.

50. Deborah Tannen, "What's in a Frame? Surface Evidence for Underlying Expectations," in Framing in Discourse, ed. Deborah Tannen (NY: Oxford University Press, 1993), 14-56.

51. Randal Beam and Damon Di Cicco, "When Women Run the Newsroom: Management Change, Gender, and the News," Journalism \& Mass Communication Quarterly 87 (summer 2010): 393-411; Stephanie Craft and Wayne Wanta, "Women in the Newsroom: Influences of Female Editors and Reporters on the News Agenda," Journalism \& Mass Communication Quarterly 81 (winter 2004): 124-38; John Sutcliffe, Martha Lee, and Walter Soderlund, "Women and Crisis Reporting: Television News Coverage of Political Crises in the Caribbean," The Harvard International Journal of Press/Politics 10 (summer 2005): 99-124.

52. Braden, She Said What?; Everbach and Flournoy, "Women Leave Journalism." 
53. Tracy Everbach, "The Culture of a Women-Led Newspaper: An Ethnographic Study of the Sarasota Herald-Tribune," Journalism \& Mass Communication Quarterly 83 (fall 2006): 477-93; Teresa Correa and Dustin Harp, "Women Matter in Newsrooms: How Power and Critical Mass Relate to the Coverage of the HPV Vaccine," Journalism \& Mass Communication Quarterly 88 (spring 2011): 301-29.

54. Anita Day and Guy Golan, "Source and Content Diversity in Op-Ed Pages: Assessing Editorial Strategies in The New York Times and The Washington Post," Journalism Studies 6 (January 2005): 61-71, 62.

55. While the Wall Street Journal has a larger circulation than the New York Times, we chose the latter for its focus on general news rather than economic and business topics.

56. Even when syndicated, the columns could have different headlines from one newspaper to another. Also, as we were interested in editorial writing, we excluded book reviews, letters to the editor, and similar entries, although these were sometime listed in the opinion section of the newspapers analyzed.

57. The categories were the following: Armed Forces, Arts, Business and Economics, Crime, Culinary, Education, Energy, Entertainment, Fashion, Food, Gardening, Gender Issues, Health, Home Improvement/Decorating, Legal Affairs, Parenting, Politics, Real Estate, Religion, Science, Sports, Sustainability/Green Efforts, Technology, Transportation, Travel, and other.

58. For instance, Correa and Harp, "Women Matter in Newsrooms."

59. Byerly and Ross, Women and Media; Ross, Women, Politics, Media; Ross, "The Journalist, the Housewife, the Citizen and the Press"; Vavrus, Postfeminist News.

60. To a great extent, due to discussion regarding a stadium for the Minnesota Vikings.

61. For instance, Gaye Tuchman, "Objectivity as Strategic Ritual: An Examination of Newsman's Notion of Objectivity," American Journal of Sociology 77 (January 1972): 660-79.

62. Juliette Kayyem, "Saudi Arabia's Un-Olympic Spirit," The Boston Globe, April 26, 2012, http://www.bostonglobe.com/opinion/2012/04/26/saudi-arabia-olympic-spirit-saudigames/tJJMYyapl7cwX8Ct2MTMXK/story.html (accessed March 7, 2014).

63. LaDawn Fletcher, "We Have to Talk about Child Abuse," The Dallas Morning News, October 11, 2011, http:/www.dallasnews.com/opinion/local-voices/headlines/20111111ladawn-fletcher-we-have-to-talk-about-child-abuse.ece (accessed March 7, 2014).

64. Ada Brown, "My Dad Had It Worse, but Discrimination Is Alive and Well," The Dallas Morning News, October 7, 2011, http:/www.dallasnews.com/opinion/local-voices/ headlines/20111007-ada-brown-my-dad-had-it-worse-but-discrimination-is-alive-andwell.ece (accessed March 7, 2014).

65. Joanna Weiss, "Marriage, Managers, 'Mommy Wars,"” The Boston Globe, April 3, 2012, http://bostonglobe.com/opinion/2012/04/02/marriage-managers-mommy-wars/ukC0mVlnqqorrQ51HV9MfM/story.html (accessed March 7, 2014).

66. Joan Wickersham, "The Bunny Who Stayed withUs," The Boston Globe, April 6,2012, http://www. bostonglobe.com/opinion/2012/04/05/bunny-who-stayed-with/UV3js9zG5uZPd2ojYMZFbM/ story.html (accessed March 7, 2014).

67. Joan Vennochi, "Pope's Ire Aimed at Wrong Target," The Boston Globe, April 22, 2012, http://www.bostonglobe.com/opinion/2012/04/22/pope-ire-aimed-wrong-target-pope-ireaimed-wrong-target/Vq6Z29aHSQVKHelcae2X9I/story.html (accessed March 7, 2014).

68. See, for example, Everbach and Flournoy, "Women Leave Journalism."

69. Braden, She Said What? 
70. Len-Rios et al., "Representation of Women in News and Photos."

71. Steiner, "Feminist Media Studies."

72. B. Hannah Rockwell, "An Ethics of Dialogue and Community: Reflections on Interdisciplinary Gender Scholarship," Women \& Language 31 (fall 2008): 22-25.

73. Rockwell, "An Ethics of Dialogue and Community," 23. 